\title{
Representação semântica e nomeação em crianças com distúrbio específico de linguagem ${ }^{* * * *}$
}

\author{
Semantic representation and naming in children with specific \\ language impairment
}

\author{
Debora Maria Befi-Lopes * \\ Cintia Preto Ferreira da Silva** \\ Ana Carolina Paiva Bento***
}

*Fonoaudióloga. Livre-Docente do Curso de Fonoaudiologia da Faculdade de Medicina da Universidade de São Paulo (FMUSP). Professora Associada do Departamento de Fisioterapia, Fonoaudiologia e Terapia Ocupacional da FMUSP. Endereço para correspondência: Rua Cipotânea, 51 São Paulo - SP - CEP 05360-000 (dmblopes@usp.br).

**Fonoaudióloga Clínica. Especialista em Fonoaudiologia pela Universidade de São Paulo (USP)

***Fonoaudióloga. Mestre em Comunicação Humana pela USP. Bolsista de Pós-Graduação (Nível Doutorado) pela USP - Agência de Fomento - Coordenação de Aperfeiçoamento de Pessoal de Nível Superior (Capes).

****Trabalho Realizado no Laboratório de Investigação Fonoaudiológica em Alterações do Desenvolvimento da Linguagem.

Artigo Original de Pesquisa

Artigo Submetido a Avaliação por Pares

Conflito de Interesse: não

Recebido em 15.05.2009.

Revisado em 01.12.2009; 10.03.2010; 30.03.2010.

Aceito para Publicação em 22.04.2010.

\begin{abstract}
Background: children with Specific Language Impairment (SLI) show lexical deficits as the first noticeable sign of such disorder, characterized as difficulties in lexical access during naming and speech tests. Studies that compare picture naming and drawings seem perfect to clarify lexical deficits. Aim: to compare the performance of children with normal language development (NLD) to that of children with SLI in naming, drawing and definition tasks, aiming to explore the the quality of semantic representation of the lexicon. Method: Two groups were involved in this study: the Control Group (CG), with no language disorders, composed by 40 subjects, and the Research Group (RG), with 20 subjects, all diagnosed with SLI, aging from five to seven years. Tasks of naming, picture drawing and definition were performed, using 20 different pictures. In the naming task, the types of errors were analyzed and sorted as follows: semantic, phonological, none specified and others. The analysis of the drawing and definition tasks was based only on the correct answers, semantic and none specified errors. Results: children of the RG presented a greater number of semantic errors in the picture naming task when compared to the CG. Besides that, definitions presented by the RG seemed more simple and incomplete even when the child was capable of naming the picture correctly. Drawings of correctly named objects were better than those that were named incorrectly. Conclusions: it was possible to discriminate within SLI children those that present greater lexical deficits. It was also possible to explore the possible reasons for failures in naming tasks.
\end{abstract}

Key Words: Language Development Disorders; Child; Semantics; Design.

\section{Resumo}

Tema: crianças com distúrbio específico de linguagem (DEL) apresentam déficits lexicais como os primeiros sinais observáveis nesta desordem, caracterizado por dificuldades de acesso lexical em provas de nomeação e discurso. Estudos comparando a nomeação de figuras com desenhos parecem ideais para esclarecer os déficits lexicais. Objetivo: comparar o desempenho de crianças em desenvolvimento normal de linguagem (DNL) com crianças com DEL nas tarefas de nomeação, desenho e definição, visando explorar a qualidade da representação semântica no léxico. Método: participaram deste estudo dois grupos: grupo controle (GC), sem alterações de linguagem, composto por 40 sujeitos, e grupo pesquisa (GP), 20 sujeitos, com diagnóstico de DEL, compreendido na faixa etária de cinco a sete anos de idade. Foram realizadas tarefas de nomeação, desenho de figuras e definição em que foram utilizadas 20 figuras. Na nomeação, os tipos de erros foram analisados e classificados em: erros semânticos, fonológicos, indeterminados e outros. A análise dos desenhos e das definições foi baseada somente no correto, nos erros semânticos e nos erros indeterminados. Resultados: as crianças do GP apresentaram maior número de erros do tipo semânticos na nomeação das figuras. Além disso, as definições do GP se mostraram mais rudimentares e incompletas mesmo quando a criança foi capaz de nomear corretamente as figuras. Os desenhos de objetos nomeados corretamente foram superiores aos desenhos de objetos nomeados incorretamente. Conclusões: foi possível diferenciar as crianças, dentro do quadro de DEL, que apresentam maiores déficits lexicais, além de possibilitar a exploração da razão das falhas em provas de nomeação. Palavras-Chave: Transtornos do Desenvolvimento da Linguagem; Criança; Semântica; Desenho.

Referenciar este material como:

1 Befi-Lopes DM, Silva CPF, Bento ACP. Semantic representation and naming in children with specific language impairment (original title: Representação semântica $\sum 3$ e nomeação em crianças com distúrbio específico de linguagem). Pró-Fono Revista de Atualização Científica. 2010 abr-jun;22(2):113-18. 


\section{Introduction}

Children with Specific Language Impairment (SLI) have deficits in learning and using language besides morphosyntactic difficulties. However, lexical deficits are the first observable signs of the disorder 1.

Authors have proposed the storage hypothesis (semantic representation) as the causal factor for the frequently observed naming difficulties of children with SLI 2.

To explore the stored representations of children with SLI is not a simple task. Simply asking the children what they know about the words quoted is not an efficient method. Because of language deficits presented, these children often lack sufficient metalinguistic knowledge to verbally define their knowledge about a word3.

Thus, researchers have used both naming tasks - analyzing the types of errors (phonological, semantic, or both) - and drawing tasks to test the storage hypothesis (representation). This is based on the rationale that evidence of storage deficit can be obtained through two different methods that underlie the same representation. This way, if the focus of the naming errors is in storage - that is, in the lexical semantic representation - the child should demonstrate difficulties in both tasks - naming and drawing3.

In case of young children, poor quality drawings may be the result of limited artistic ability. Thus, the key to the comparative study between picture/ naming and picture/drawing is a comparison between drawings of correctly named objects and drawings of incorrectly named objects3. Correct naming reflects an appropriate representation on the semantic locus. This way, drawings of objects correctly named should be of superior quality than the drawings of incorrectly named objects no matter the overall artistic ability.

Therefore, the purpose of the present study is to compare the performance of normal developing children and children with SLI on tasks of naming, drawing and definition, in order to explore the quality of their semantic representation in the lexicon. We assume that objects correctly named have better semantic representation in the lexicon of children, both normal and SLI.

\section{Methods}

The study included two groups of children: Control Group (CG) and Study Group (SG) at a ratio of 2:1 (control:study).
This study was reviewed and approved by the Ethics Committee of the Department of Physical Therapy, Speech Language and Hearing Sciences, and Occupational Therapy of the Medical School of University of Sao Paulo (FMUSP), under number $044 / 05$. The consent forms were signed by parents or guardians of children of both groups.

The CG was composed of 40 children of both genders with an average age of 6.34 years (5;3 and 7;11 years). All children from the CG were students at a state school in the northern region of São Paulo.

The inclusion criteria for the CG were: absence of complaints or previous speech therapy, good communicative pattern and satisfactory academic performance according to their teachers. Furthermore, they should provide adequate performance in the tests of Phonology4, Expressive Vocabulary5 and Receptive Vocabulary6.

The SG was composed of 20 children of both genders diagnosed with Specific Language Impairment (SLI) and an average age of 6.34 years (5:0 and 7:8 years). All children from the SG attended speech therapy in the Laboratory for Language Development and Disorders Research (Laboratório de Investigação Fonoaudiológica em Desenvolvimento da Linguagem e suas Alterações (LIF-ADL) of the Physical Therapy, Speech Language and Hearing Sciences, and Occupational Therapy of FMUSP.

This study was based on a research carried out at the Northwestern University Evanston7 in which the semantic representation and naming in children with SLI was investigated.

Twenty black and white pictures of objects were used to elicit naming, drawings and definitions $8,9,10$. The pictures were chosen according to the frequency of occurrence in Brazilian-Portuguese10. The material was selected for being a Brazilian standard used on the research that served as basis for the present study.

Pictures representing words of average frequency of occurrence and with age-appropriated level to the participants were selected. This was done in order to balance the need to elicit errors and to ensure the probability that the child had some knowledge about the stimulus. The visual complexity of the twenty stimuli was analyzed in order to ensure that naming responses and drawings would not be influenced by the visual complexity of the pictures.

Participants of the CG were individually tested in their schools. Participants of the SG were tested at Laboratory for Language Development and Disorders Research (LIF ADL) of the Physical Therapy, Speech Language and Hearing Sciences, 
and Occupational Therapy of FMUSP.

The tests used as inclusion criteria for the CG were performed during the first session, the naming tasks during the second session, half of the drawing and definition tasks during the third session, and the other half of the drawing and definition tasks were carried out during the fourth session.

The same order was followed for the SG. However, the SG had one less session because tests for inclusion were not used for this group. The items drawn and defined during each session were randomly selected to ensure that participants would not draw and define the same object in the same session. The interval between sessions was between two and fifteen days.

The responses obtained in the naming task were classified according to four types of errors: semantic errors, phonological errors, indeterminate errors and others 7:

Semantic errors were divided into:

1A) Taxonomic: errors involving associations within the semantic category.

1.1 coordinated substitutions: use of semantically similar words;

1.2 superordinated substitutions: replacement for a semantically more comprehensive word.

2A) Thematic: errors involving associations outside the semantic category.

2.1 New derivates: substitution by diminutives, augmentatives or any derivation of the target word; 3A) Descriptive:

3.1 Circumlocution: repeated use of paraphrases rather than the name of the object;

Errors of non-semantic nature were classified as:

1B) Phonological errors: replacement of the target word for a real or non-real word which approaches the form of the target word;

1C) Indeterminate errors: responses as "I do not know";

1D) Other: none of the previous classification or unintelligible responses.

The analysis of drawings and definitions were based only on correct responses, semantic errors and indeterminate errors.

The information contained on the definitions was explored to determine whether there were qualitative differences in the type of semantic storage associated with correct and incorrect naming. The amount and type of information provided in each definition were considered. Five adults who were unaware of the target responses of the naming task were judges of the study. This standard was used to avoid the confusion between limited artistic ability to drawing and a constrained semantic representation. These judges scored the accuracy of each drawing through a scale of agreement and disagreement with the sentence "The drawing of this child reflects precision and complete knowledge of $\mathrm{X}$ ". The scale ranged from 1 to 7 . The scores between 1 and 2 reflect a high disagreement on the drawing accuracy; scores between 2.01 and 5.99 reflect a moderate agreement; and scores between 6 and 7 reflect a strong agreement. Disagreements were resolved by common sense.

\section{Results}

For statistical analysis we used the following tests: ANOVA, t test for independent samples and chi-square. The significance level adopted was of $5 \%$.

Values of mean, median, and overall and by age standard deviations for each group are displayed in Tables 1 and 2.

Participants of CG did not show variation in performance among tasks $(\mathrm{F}=0.88, \mathrm{p}=0.417)$. In contrast, participants of SG performed significantly better in the naming task as compared to the definition and drawing tasks $(F=7,70, p=0.001)$. Comparing the two groups for each task, statistically significant better performances on the naming $(\mathrm{T}=$ 4.50, $\mathrm{P}<0.001)$, drawing $(\mathrm{T}=6.39, \mathrm{P}<0.001)$ and definition ( $\mathrm{T}=4,26, \mathrm{P}<0.001)$ tasks were observed for the $\mathrm{CG}$.

The groups did not differ on the naming task for five-year old subjects ( $\mathrm{T}=1.89, \mathrm{p}=0.155)$. In contrast, CG performance was superior for six-year old subjects ( $T=2.41, \mathrm{p}=0.039)$ and for seven-year old subjects $(\mathrm{T}=4.18, \mathrm{p}=0.009)$. The same pattern was observed for the definition and drawing tasks: similar performance for five-year olds $(\mathrm{T}=2.57, \mathrm{p}=$ 0.083 and $\mathrm{T}=1.84, \mathrm{p}=0.163)$ and better $\mathrm{CG}$ performance for six-year olds $(T=5,77, p=0,0,001$, and $\mathrm{T}=5.76, \mathrm{p}=0.001)$, and seven-year olds $(\mathrm{T}=$ 5.29, $\mathrm{p}=0.013$ and $\mathrm{T}=3.62, \mathrm{p}=0.036$ ).

Regarding the types of errors presented in the naming task by the CG, 35.7\% (11) were semantic, $3.6 \%$ (1) were phonological and 57.14\% (16) were indeterminate. For the SG, 65.1\% (28) of the errors were semantic, $46.4 \%$ (13) were indeterminate, and $4.6 \%$ (2) were of the type other. Thus, the most predominant error type for the CG was the indeterminate and for the SG was the semantic type. This difference was statistically significant (X2 = 5.052; $\mathrm{df}=1, \mathrm{p}=0.025$ ). 
Regarding the typology of errors presented in the drawing task by the CG, 83.3\% (36) were semantic and $16.7 \%$ (6) were indeterminate. For the SG, $80.2 \%$ (69) of the errors were semantic and $19.77 \%$ (17) were indeterminate. Thus, the groups did not differ regarding the typology of errors in the drawing task $(\mathrm{X} 2=0.159 ; \mathrm{df}=1, \mathrm{p}=0.690)$.
In the analysis of the errors of the definition task, $65.7 \%$ (23) of errors of the CG were semantic and $34.4 \%$ (12) were indeterminate. For the SG, 70.2\% (66) of errors were semantic and $29.8 \%$ (28) were indeterminate. Similarly to the drawing task, the groups did not differ regarding the types of errors $(\mathrm{X} 2=0.241 ; \mathrm{ngl}=1, \mathrm{p}=0.623)$.

TABLE 1. Values of mean, median and standard deviation for each task of the CG.

\begin{tabular}{|c|c|c|c|c|}
\hline Task & Age & Mean & Median & SD \\
\hline \multirow[t]{4}{*}{ Naming } & 5 & 19,38 & 19,00 & 0,52 \\
\hline & 6 & 19,00 & 19,50 & 1,18 \\
\hline & 7 & 19,00 & 19,00 & 0,93 \\
\hline & Overall & 19,10 & 19,00 & 0,96 \\
\hline \multirow[t]{4}{*}{ Drawing } & 5 & 18,13 & 18,00 & 0,84 \\
\hline & 6 & 19,07 & 19,00 & 0,73 \\
\hline & 7 & 19,13 & 19,00 & 0,35 \\
\hline & Overall & 18,83 & 19,00 & 0,79 \\
\hline \multirow[t]{4}{*}{ Definition } & 5 & 18,25 & 18,50 & 0,89 \\
\hline & 6 & 19,14 & 19,00 & 0,66 \\
\hline & 7 & 19,00 & 19,00 & 0,54 \\
\hline & Overall & 18,87 & 19,00 & 0,78 \\
\hline
\end{tabular}

TABLE 02. Values of mean, median and standard deviation for each task of the SG.

\begin{tabular}{ccccc}
\hline Task & Age & Mean & Median & SD \\
\hline Naming & 5 & 17,25 & 17,00 & 2,22 \\
& 6 & 17,43 & 18,00 & 1,51 \\
\hline & 7 & 16,50 & 17,00 & 1,00 \\
\hline Drawing & Overall & 17,13 & 17,00 & 1,55 \\
& 5 & 13,75 & 15,50 & 4,72 \\
& 6 & 14,43 & 15,00 & 2,07 \\
& 7 & 14,50 & 15,00 & 1,73 \\
& Overall & 14,27 & 15,00 & 2,71 \\
& 5 & 12,00 & 13,50 & 4,83 \\
& 6 & 14,71 & 15,00 & 1,98 \\
& 7 & 13,75 & 14,00 & 2,87 \\
& Overall & 13,73 & 14,00 & 3,13 \\
\hline
\end{tabular}




\section{Discussion}

Types of errors

Results indicated that the SG presented a predominance of semantic errors for all tasks performed while the CG presented a predominance of semantic errors only in the drawing and defining tasks. Moreover, the number of semantic errors was significantly higher for the SG when compared to the CG.

These results corroborate to other studies in which children with SLI made more semantic than phonological substitutions in naming tasks 11,3,7,12.

According to other studies, children with SLI make more phonological substitutions during the naming tasks than their matched peers with typical development 13. In our study, the SG did not show phonological errors whereas the CG showed occurrence of this type of error.

Researchers have explored the reason for the higher number of semantic substitutions. They currently find evidence in three hypotheses. For the first hypothesis, children would make semantic substitutions to fulfill lexical gaps (the semantic representation is absent in the mental lexicon). To complete the naming task, they would use words that cover the characteristics of the target. The second hypothesis is that children would not recognize the target word enough to name it correctly (there is a weak semantic representation in the mental lexicon). With partial knowledge, they are not able to correctly choose between the target and related words. Finally, in rare cases, the children would temporarily forget the target but, however, the knowledge about the word does exist (there is good semantic representation in the mental lexicon) 3.

Moreover, the groups differed from the age range of six years, showing that the development of these skills occurs later in children with SLI. These data are consistent with recent studies 14,15.
Naming/Drawing

Our research showed that correctly named pictures were appropriately drawn in detail.

Other studies have also found a significant relationship between naming and drawing3. Drawing, for being a visual task, showed to be a valid and a potential tool for the assessment of semantic knowledge of children - especially in cases with restricted verbal knowledge 16.

\section{Noming/Definition}

The definition task shows us information about the semantic representation of children. Most of the definitions described physical and functional properties of objects. Studies have shown that physical and functional properties are the basis for the categorization of objects in infancy 17,18.

Our results showed that there is a strong relationship between the definition and the correct naming of objects - correctly named objects were more comprehensively defined. These data agree with other authors who relate the adequate semantic representation to the tasks of naming and definition of objects and their graphic representation3.

\section{Conclusions}

The results of the present study emphasize the dynamic nature of the mental lexicon of children and clarified some issues about semantic representations.

The analysis of drawings and definitions suggested that the physical and functional properties are central aspects of semantic representations.

Through the analysis of the types of errors we found that semantic representations appear to be organized and accessed according to the taxonomic hierarchy.

It was possible to differentiate children, within the SLI group, who have higher lexical deficits, in addition to explore the reason for failures in the naming task.

With this assessment, we have both a quantitative and a qualitative picture of the performance of children. This enables us to present increasingly reliable data to better direct the rehabilitation focus aiming to ensure better performance of these children in social life. 


\section{References}

1. Castro-Rebolledo R, Giraldo-Prieto M, Hincapié-Henao L, Lopera F, Pineda DA. Transtorno específico del desarollo del lenguaje: una aproximación teórica a su diagnóstico, etiología y manifestaciones clínicas. Revista de Neurología. 2004.p.1173-81.

2. Kail R, Leonard LB. Word-finding abilities in languageimpaired children. In: Mcgregor KK, Appel A. On the relation between mental representation and naming in a child with specific language impairment: Clinical Linguistics and Phonetics; 2002.

3. Mcgregor KK, Apple A. On the relation between mental representation and naming in a child with specific language impairment: Clinical Linguistics \& Phonetics; 2002.

4. Wertzner HF. Fonologia. In: Andrade CRF de, Befi-Lopes DM, Fernandes FDM, Wertzner HF. ABFW - Teste de linguagem infantil: nas áreas de fonologia, vocabulário, fluência e pragmática. Barueri: Pró-Fono; 2004. cap1.

5.Befi-Lopes DM. Vocabulário. In: Andrade CRF de, BefiLopes DM, Fernandes FDM, Wertzner HF. ABFW - Teste de linguagem infantil: nas áreas de fonologia, vocabulário, fluência e pragmática. Barueri: Pró-Fono; 2004. cap2.

6. Morselli AA, Befi-Lopes DM. Vocabulário receptivo e expressivo em crianças com desenvolvimento normal e com distúrbio específico de linguagem. Dissertação [Mestrado em Semiótica e Linguística geral]. São Paulo: Faculdade de Filosofia, Letras e Ciências Humanas. Universidade de São Paulo; 2003.

7. Mcgregor KK, Newman RM, Reilly RM, Capone NC. Semantic representation and naming in children with specific language impairment. Journal of Speech, Language, and Hearing Research; 2002a.

8. Pompéia S, Miranda MC, Bueno OFA. A set of 400 pictures standardized for Portuguese: norms for name agreement, familiarity and visual complexity for children and adults: Arquivos de Neuro-psiquiatria; 2001.
9. Pompéia S, Miranda MC, Bueno OFA. Brazilian standardized norms for a set of pictures are comparable with those obtained internationally: Arquivos de NeuroPsiquiatria; 2003.

10. Snodgrass JG, Vanderwart M. A standardized set of 260 pictures: norms for name agreement, image agreement, familiarity, and visual complexity. Journal of Experimental Psychology: Human Learning and Memory; 1980. p.174215.

11. Mcgregor KK. The nature of word-finding errors of preschoolers with and without word-finding deficits. Journal of Speech, Language, and Hearing Research. 1997.

12. Mcgregor KK, Friedman RM, Reilly RM, Newman RM. Semantic Representation and Naming in Young Children: Journal of Speech, Language, and Hearing Research. 2002b.

13. Lahey M, Edwards J. Naming errors of children with specific language impairment. Journal of Speech, Language, and Hearing Research. 1999. p.195-05.

14. Gray S. Word Learning by Preschoolers With Specific Language Impairment: effect of phonological or semantic cues. Journal of Speech, Language, and Hearing Research. 2005. p.1452-1467.

15. Nash M, Donaldson ML. Word Learning in Children With Vocabulary Deficits. Journal of Speech, Language, and Hearing Research. 2005.p.439-458.

16. Garber P, Alibili MW, Goldin-Meadow S. Knowlwdge conveyed in gesture is not tied to the hands: Child Development. 1998.p.75-84.

17. Scheuer CI, Stivanin L, Mangilli LD. Nomeção de figuras e memória em crianças: efeitos semânticos e fonológicos: Pró-Fono Rev. Atual. Cient. 2004.

18. Mandler JM. Perceptual and conceptual processes in infancy. Journal of Cognition and Development. 2000. p.3-36. 